\title{
Ruthless Polyphony and Audible Silences: \\ Musico-Dramatic Narrative in Otakar Zich's Vina
}

Brian S. Locke

\begin{abstract}
Otakar Zich's opera Vina [Guilt] met with contentious criticism at its premiere in 1922. Nevertheless, its score demonstrates many of the concepts of musico-dramatic narrative outlined in his seminal text, The Aesthetics of Dramatic Art, specifically that of multivocality - the multiple modes of communication perceived through time in continuous unfolding. Vina also employs concepts of silence and sound that resonate with Vladimir Jankélévitch's Music and the Ineffable.
\end{abstract}

\section{Key words}

opera history, musico-dramatic narrative, Otakar Zich, Vladimir Jankélévitch 
The premiere of Otakar Zich's Vina [Guilt] at Prague's National Theatre on 14 March 1922 was a much-heralded event that had been greatly anticipated for several years though not always, it should be noted, in a positive light. To be sure, Zich had strong supporters, among them the theatre's new musical director, Otakar Ostrčil, who had championed the work for many years. ${ }^{1}$ But many others in Prague's musical community anticipated a disaster, heralding the premiere with vitriol instead of praise, and questioning Zich's right to call himself a composer. The opera's musical and dramatic achievements were analyzed in detail only once, and it never gained a foothold in the permanent repertoire. Vina, when discussed at all, appears in the historiography as a cautionary tale, presaging the larger aesthetic conflicts to come. ${ }^{2}$

Paradoxically, Zich's most significant composition would be remembered less for its musico-dramatic content than for its stormy critical reception, caught in the crosshairs of Prague's partisan cultural politics and a pervasive distrust of musical modernism. ${ }^{3}$ Nevertheless, the score of Vina represents several landmarks: for one, as I assert, it was the first Czech opera to contain pervasive post-tonal elements in its harmonic language; furthermore, it represents the direct manifestation of Zich's own aesthetics of music and theatre, contributions for which he is justifiably heralded to this day.

The music and drama of Vina require a detailed understanding in the context of Zich's own theories, especially those found in his monumental Estetika dramatického uměni (The Aesthetics of Dramatic Art), as well as the shorter essays, just as Zich's writings are enriched by knowledge of his music (ZICH 1977 [1931], 1927a and 1927b). In this article, I will discuss how Zich's concept of dramatic 'multivocality' - multiple modes of communication perceived through time in continuous unfolding - is manifested in Vina's score, in both its harmonic language and its polyphonic musical texture (the interaction of vocal and orchestral parts). My acquaintance with Zich's music stems from 2005, when I began work on a scholarly edition of Vina in full score, for which I drew upon the performance materials housed at the Music Archive of the National Theatre. These included, among other items, a hand-written orchestral score, some 987 pages in length: for despite Vina's notoriety, only a three-page excerpt had ever

1 Ostrčil was music director at the Vinohrady Theatre in 1915 when Zich first completed Vina, and from that year onwards campaigned for its inclusion among the seasons' premieres both under his own baton at Vinohrady and under that of Karel Kovařovic at the National Theatre. Both efforts initially failed: modernist repertoire suggestions such as Vina provoked the conservative directorate of the Vinohrady Theatre to close its opera department definitively in 1919, sparking a small controversy in Prague musical circles; and Kovařovic, soon to devote his remaining energies to the premiere of Janáček's Jenñfa, rejected Vina without much consideration. When Ostrčil became Kovařovic's dramaturge in 1919, Vina appeared among his first repertoire suggestions, and after the latter's death in 1920, it became one of Ostrčil's first new productions, supplanting both Vítězslav Novák's Lucerna and his own Legenda $z$ Erinu. The première cast included Gabriela Horvátová (Mína), Věra Pivoňková (Paní Mařáková), Miloslav Jeník (Hošek), Jan Konstantin (Jiří), and Luděk Mandaus (Uhlî́). See an extensive discussion in (PALA 1964: 102-104).

2 Chief among these debates over musical modernism in Prague was the notorious 'Wozzeck Affair' of 1926, in which the reception of Vina was mentioned repeatedly. For further reading, see (LOCKE 2008: 63-93).

3 An excellent cross-section of the critical response can be found in Tempo - Listy Hudebni matice 1 (April 1922): 7: 104-107. 
been published. ${ }^{4}$ The resulting three-volume edition was published in 2014 by A-R Editions (ZICH 2014). I will also draw on the work of the French philosopher Vladimir Jankélévitch, a student of Bergson who resided in Prague between 1927 and 1933, and who may have had contact with the Prague Linguistic Circle. Jankélévitch's 1961 text Music and the Ineffable speaks to his lifelong rumination on the perception and ontology of expressive sound and - importantly for understanding Zich's work - the role of silence in music. ${ }^{5}$ For this is another paradox of Zich's Vina: at the height of its most complex, full-orchestral, post-tonal polyphony, its composer sought to embody things unspoken or even inexpressible.

\section{Zich's polemic position}

The complex legacy of Zich's achievement reflects the deep institutional and disciplinary divisions of Czech musical society that prevailed in Zich's time between Prague Conservatory and the music professors at Charles University. For although Zich was raised in a multigenerational family of musicians - an environment suffused with detailed listening and score study from childhood - and he composed, edited, and wrote about music for nearly forty years, these efforts were unilaterally rejected by the élite musicians of Prague Conservatory (ZICH 1933). As Josef Hutter wrote in 1922:

I am convinced that there is no more contentious artistic personality in Czech music in the last twenty years than Otakar Zich. Contentious, though [in a manner] duly relative to the situation. In fact, it has nothing to do with an artistic polemic over a known work, but rather the contentiousness of an incomprehensible question: is Zich a composer at all, or not? An incomprehensible question, because Zich's work is certainly spoken about, whispered about, hyped up, and cast down, but in reality, nobody knows his works, even down to the most minute fragments. (HUTTER 1922) ${ }^{6}$

4 All performance materials were found in the collection of Hudebni Archiv, Národni divadlo v Praze, MS. $\mathrm{H}$ 177. These include a three-volume full score, a complete set of orchestral parts, two piano-vocal scores (one possibly in Zich's own hand, with an interlinear German translation; the other a prompt book, 'Nápovéda'), several libretti, and a stage-director's book ('Inspicie') consisting of an adapted copy of Jaroslav Hilbert's play annotated with musical cues. The three-page Píseñ pani Mařákové was published in Prague by Nakladatel Em. Starý, 1922.

$5 \quad$ Vladimir Jankélévitch (1903-1985) studied with Henri Bergson in the years 1922-1924 at the École normale supérieure in Paris. His first academic post was at the Institut Français de Prague, 1927-1933, during which he published his authoritative study of Bergson (1931). While in Prague, Jankélévitch began demonstrating philosophical concepts to his students by performing excerpts of piano music himself. In later years, teaching in Lyon, Toulouse, Lille, and the Sorbonne, he became the frequent piano duet partner of fellow philosopher and audiophile Roland Barthes. In 1938 he published his first work to combine music, aesthetics, and philosophy (Gabriel Fauré, ses mélodies, son esthétique, revised 1951); this was followed by many others (including Ravel, 1939; Debussy et le mystère de l'instant, 1949; Liszt et la Rhapsodie, 1976). He is chiefly known among Anglo-American musicologists for La musique et l'ineffable (1961), translated by Carolyn Abbate as Music and the Ineffable (JANKÉLÉVITCH 2003).

$6 \quad$ All translations are my own unless otherwise stated. 
Zich was no passive victim of these polemics, and his active participation in the critical attacks on Dvořák, Janáček, and others engineered by Zdeněk Nejedlý in the years 1911-1918 undoubtedly cast a long shadow over Zich's musical achievements. ${ }^{7}$ To this day, Hutter's words ring true: Zich's name is almost always listed alongside his contemporaries Novák, Suk, Foerster, and Ostrčil, but most of his scores have yet to be studied.

Rather, it is his contributions to aesthetics and theatre studies, not to mention his mentorship of the Prague Linguistic Circle, that have resonated through academic discourse in the Czech sphere and beyond. Within this rich and lengthy bibliography, Zich's compositional life appears as a curious footnote, a trace of a world of sound that has fallen silent, inaccessible to nonmusicians. Nevertheless, it is evident that Zich's treatises on aesthetics, perception, and dramatic theory owe much to his musical experiences, which served as his continuous point of reference. Despite the curious fact that Zich advises his nonmusical readers to skip over the opera chapter in his preface to The Aesthetics of Dramatic Art (1931), he remarked that 'I was led to these ideas by my own artistic practice [...]. Having worked on my operas, I have been able to use my own compositional experience in support of [my new concepts]'(ZICH 1931: 9-10). ${ }^{8}$ Although most of his examples come from the operas of Gluck, Weber, Wagner, and Smetana, Zich singled out Vina from his own æeuvre in ways that reflect both his artistic and theoretical perspective.

\section{Vina: motifs and multivocality}

In his choice of Jaroslav Hilbert's 1896 play, Zich found in Vina a rich source of what was termed 'psychological realism': a movement that reflected contemporary Czech interest in the work of Henrik Ibsen and Émile Zola, with their blend of social critique and psychologically driven tragedy. Written to showcase the actress Hana Kvapilová, the play was a highlight of the 1890s at Prague's National Theatre (JUSOVÁ 2004: 35-56). Zich based his libretto almost directly on Hilbert's original text with cuts for length and flow, but otherwise without substantial semantic changes. He probably began work on Vina shortly after the premiere of his first opera, Maliŕský nápad [The Painter's Idea], on 11 March 1910, for as Josef Burjanek notes,

Even in the midst of such demanding compositional exertions he was thinking in two different directions. For one, he was clarifying operatic dramaturgy in a theoretical way for himself; [...] for the other, he thought through the relationship of music to human emotions, from which definitively developed the most weighty aesthetic theme of his entire future life, which

7 For further discussion on the Nejedlý circle and Zich's role in it, see (LOCKE 2006: 48-58).

8 Zich's recommendation appears as follows: 'This chapter, although not assuming an expert knowledge of music on the part of the reader, will, nevertheless be written primarily for musicians. Those who are interested in spoken drama exclusively may skip it' (ZICH, transl. by OSOLSOBĚ n.d.: 370). 
is to say, the question of music's effect on human consciousness and its relation to [...] the reality of the world. (BURJANEK 1966: 22) ${ }^{9}$

Echoing Ibsen, the setting of Hilbert's Vina is a single room - the parlor of a middleclass Prague family - that witnesses the painful resolution of events triggered long before. Mína Mařáková is a twenty-three-year-old woman recently engaged to her boyfriend Stanislav Hošek; despite this she suffers with unresolved guilt over her seduction by a country gentleman, Karel Uhlír, seven years ago. Her mother, Paní Mařáková, had also been in love many years before, but had been forced into a loveless marriage with Mína's late father. The result is that Paní Mařáková has showered affection only on her son Jiří (a sculptor) and has withheld her love from Mína, who is all too conscious of her mother's emotional neglect. The curtain rises to reveal this very dynamic: Mařáková's coldness toward her daughter and Mína's desperation for approval in return. Amid this latent psychological turmoil, the play's action is triggered by the arrival of Uhlír, who has come to Prague under the pretence of buying one of Jiř́'s sculptures (in fact, a portrait of Mína named 'Grief'). Once alone with Mína, however, Uhlír stakes his claim to marry her, arrogantly insisting that his prior seduction gives him this right, thus in coldly certain terms, Mína's unrelenting guilt over the past has come to destroy her present and future.

Act One of Zich's score reflects his own recommendations in Chapter 8 of The Aesthetics of Dramatic Art concerning what he terms the musico-dramatic principle:

A dramatic composer does not compose a dramatic text, but [rather] dramatic situations. He must, no doubt, use the text of the libretto as his starting point, but he must not strictly keep to it. This text serves him as a basis enabling him to reconstruct as well and as vividly as possible in his imagination the dramatic scenes, their change, and succession, [...] and in this attitude he begins his own creative work. (ZICH, transl. by OSOLSOBĚ n.d.: 427-428)

For Zich, the temporal unfolding of the dramatic situation was of primary importance. The composer's choice of tempos was also 'a very delicate matter', for the operatic score binds the dramatic action even more strictly than the actor's performance in a stage play (ZICH, transl. by OSOLSOBĚ n.d.: 430). Zich also gives greater weight to orchestral music over the vocal lines - a notion that may strike us as somewhat antithetical to the operatic genre. This overbalance stems partly from his post-Wagnerian inheritance, through which the melodic motifs appear primarily in the orchestra, below the dramatic declamation of the singers. Orchestral music also served many important functions in Zich's musico-dramatic principle, the least of which was direct mimicry of sounds from everyday life: rather, it conveyed indirect, symbolic description of facets of the drama, including the characters' emotions and states of mind. Zich in this way describes the simultaneousness or 'multivocality' of opera as drama, in that the com-

$9 \quad$ Zich concluded his sketch of Act 1 on 29 October 1911 and the full score of the entire opera on 24 March 1915. 


Libretto $\rightarrow \quad$ Score with tempos $\rightarrow \quad \begin{aligned} & \text { progress in time } \\ & \text { is fixed }\end{aligned}$
$\begin{aligned} & \text { Orchestral } \\ & \text { Music }\end{aligned} \quad \begin{aligned} & \text { Vocal } \\ & \text { Music }\end{aligned}$

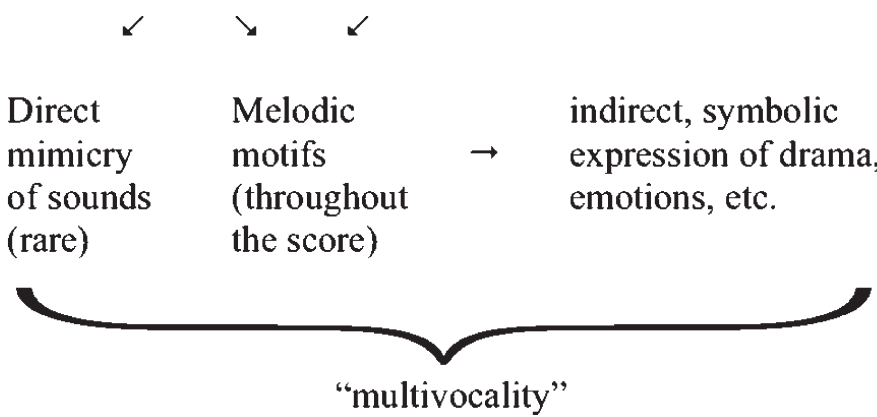

Fig. 1: Zich's multivocality within the musico-dramatic principle

poser enacts the transfer of both visual and emotive phenomena from the stage to the acoustic sphere, where they are perceived by the audience in association and become inseparable from other elements of the drama (see Fig. 1). ${ }^{10}$ These musical emotions have a 'dynamic aspect with respect to their progress in time [...], i.e., the change of intensity and the speed characteristic of certain emotions and endeavours or their combination' (ZICH, transl. by OSOLSOBĚ n.d.: 389).

Zich's score employs a web of musical Leitmotifs: small fragments of melody in a continuously developing, open orchestral texture. Identifying motifs with plot elements is also a post-Wagnerian inheritance: for characters (here, everyone except Mina), events (the 'confession' motif), and psychological states ('guilt,' 'love,' 'resignation,' 'grief,' 'defiance,' and many others). Most of these were identified by Josef Hutter in his analysis published to coincide with Vina's premiere, presumably with Zich's approval. ${ }^{11}$ Many of these are related back to the 'guilt' motif (see Example 1), which the composer names specifically in The Aesthetics of Dramatic Art:

The first idea that struck me in connection with my opera Vina before I started to work at it systematically was a moment from the middle of the third act, when Mína confesses her guilt to her mother and brother in chilly despair. It was the first singing melody of her confession, 'I am a fallen, impure girl...,' combined with the accompanying orchestral music, and it,

10 The concept of multivocality is one that pervades Zich's chapter 8: 'Dramatic music. The Composer's Creative Work' (ZICH, transl. by OSOLSOBĚ n.d.: 370-476, especially 434).

11 The motivic designations are given in (HUTTER 1922: 45-61). They are also replicated in (ZICH, ed. LOCKE 2014a: ix-x). 
Table 1: Motifs in Zich's Vina

\section{Symmetrical}

Guilt

Paní Mařáková

Uhlír

Love

Resignation

Confession

Coldness

Grief

Suffering

\section{Asymmetrical}

Hošek

Jiŕi

Affection

Condemnation

Dishonour

Defiance

Death

Nature

naturally, became 'the guilt motive,' interweaving [throughout] the whole opera in numerous variations, some of which the listener hears before the original form, which agrees with the dramatic idea of the work. (ZICH, transl. by OSOLSOBĚ n.d.: 440)

(1) The 'Guilt' motif. Otakar Zich, Vina, Act 1, mm. 65-71.

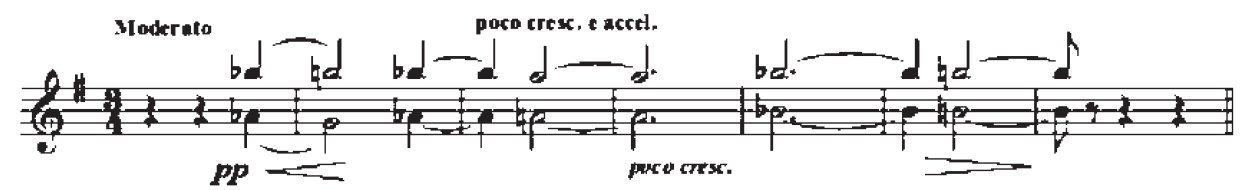

Many of the other motifs named by Hutter share a similar contour with 'guilt', namely its melodic symmetry (see Table 1). Thus, Zich's motivic web has much in common with Arnold Schönberg's concept of Grundgestalt or 'basic shape', from which almost all other musical materials are derived. ${ }^{12}$ Doing so 'agrees with the dramatic idea of the work,' since all elements revolve around Mína's perception of her own guilt (see Example 2).

12 Schönberg's concept of Grundgestalt arose from his early teaching, circa 1906-1910. As he put it later, 'Whatever happens in a piece of music is the endless reshaping of the basic shape ... There is nothing in a piece of music but what comes from the theme, springs from it and can be traced back to it; to put it still more severely, nothing but the theme itself' (SCHOENBERG 1950: 289-295; SCHIANO 2001). 
(2) Zich's Grundgestalt based on the 'Guilt' motif:

a. 'Guilt' motif (chordal variant), Act 1, mm. 722-26.

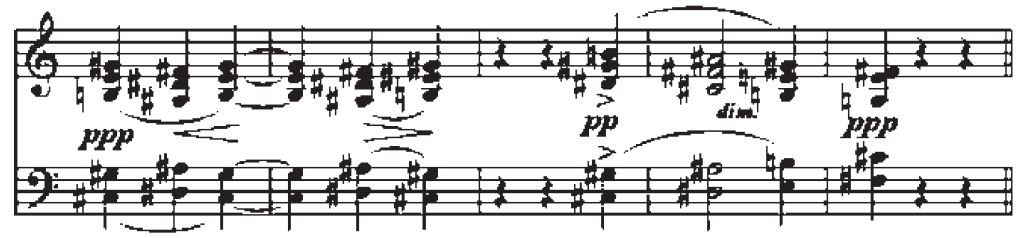

b. Paní Mařáková's motif, Act 1, mm. 1-3.

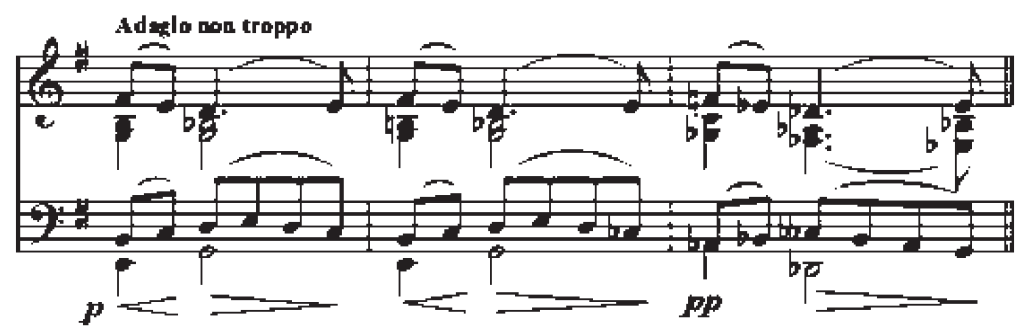

c. 'Love' motif, Act 1, mm. 15-19.

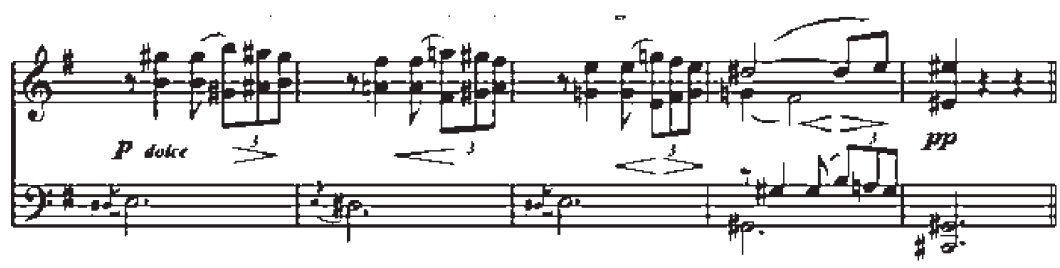

d. 'Resignation' motif, Act 3, mm. 2-6.

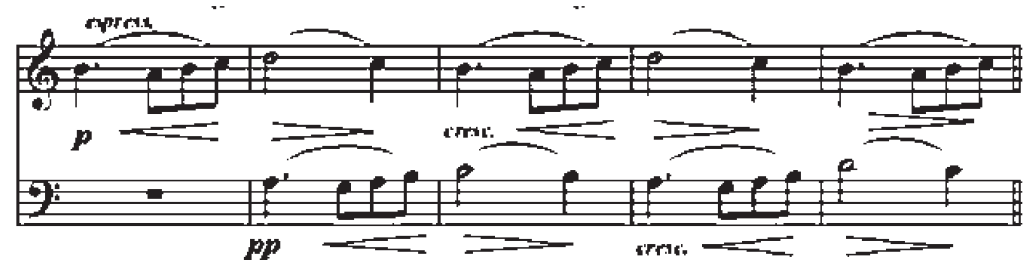




\section{e. Uhliřs's motif, Act 1, mm. 1028-31.}

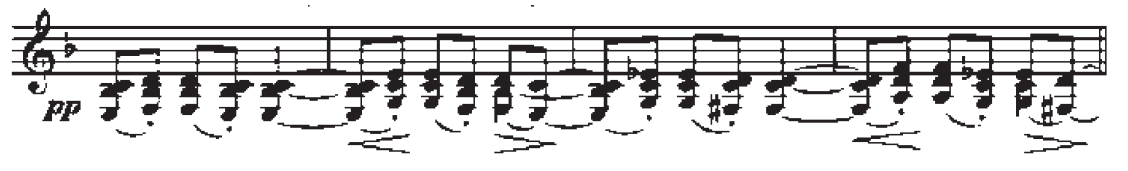

f. 'Suffering' motif, Act 3, mm. 421-24.

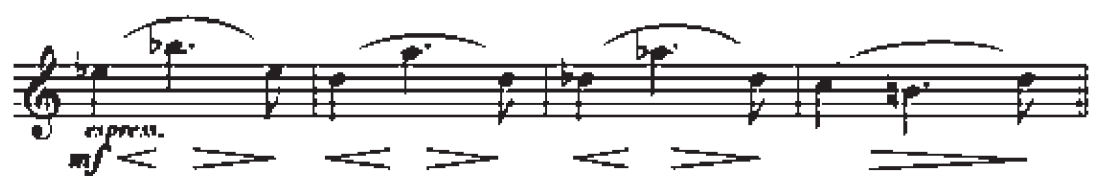

This also, in a way, explains a lacuna in the list of motifs: Mína has no motif of her own. Rather, with few exceptions, it is the entire orchestral score, resonating with the music of her guilt, that represents Mína's psychological state. This makes her the close cousin of Richard Strauss's Elektra, which Zich had analyzed in 1910 for his article 'Moderni opera' [Modern Opera] (ZICH 1914: 481-493, 569-579). In Elektra the orchestral forces not only represent the title character, but as we are led to imagine, emanate from her very being. What we hear is her sound world: tellingly, when asked in the final scene whether she can hear the musical celebration of her mother's downfall, she responds, 'Ob ich die Musik nicht höre? Sie kommt doch aus mir [As if I did not hear the music? Indeed, it is coming from me]' (ABBATE 1991: 134-135). Zich's Mína might intone the very same sentiment. The composer remarks on the orchestra's role within the psychological trajectory in The Aesthetics of Dramatic Art:

The orchestra music can betray to us even such ideas and thoughts which were not uttered at all [...]. This delicate capacity of musical-psychological descriptiveness asserts itself particularly in the psychological music dramas, the most suitable means being its polyphony, which is above all capable of describing the states of mental derailment. (ZICH, transl. by OSOLSOBĚ n.d.: 459)

This is precisely what happens in the larger musico-dramatic narrative of Vina: as the heroine begins to lose her grip on rational thought, so too do the melodic motifs come unmoored from their harmonic underpinnings by means of polyphonic development across Zich's vast orchestra.

Zich composed during a generation that witnessed (and participated in) the breakdown of functional tonality: the inherited syntax of how chords relate to each other and how they progress across phrases, with dissonances resolving to consonances. The threshold of acceptable dissonance was accelerating toward non-functional tonality (where recognizable chords no longer related to each other) and free atonal- 
ity, notoriously described by Schönberg in the 1920s as 'the emancipation of the dissonance. ${ }^{13}$ As chords were no longer bound by syntax, their notes were thus freer to move as independent, simultaneous polyphonic melodies. Polyphony is itself a much older compositional device, but modernist, post-tonal composers of the early twentieth century frequently used it as a means of disrupting the musical texture. No longer bound by functional tonal syntax, development of motifs in a polyphonic setting could create complex linear structures horizontally across the page, which is to say, through time.

Table 2: Harmonic Plot of Vina

\begin{tabular}{|c|c|c|}
\hline Act One & Act Two & Act Three \\
\hline $\begin{array}{c}\text { Functional Harmony } \\
\text { (Tonal) }\end{array}$ & $\begin{array}{c}\text { Non-functional Harmony } \\
\text { (Polytonal) }\end{array}$ & $\begin{array}{c}\text { Free Atonality } \\
\text { (Post-tonal) }\end{array}$ \\
\hline $\begin{array}{c}\text { Chords have syntax that } \\
\text { relate to each other in } \\
\text { a progression }\end{array}$ & $\begin{array}{c}\text { Chords and melodies are still } \\
\text { recognizable but may not } \\
\text { relate to each other }\end{array}$ & $\begin{array}{c}\text { Chords and melodies are } \\
\text { barely recognizable, no } \\
\text { longer bound by syntax }\end{array}$ \\
\hline $\begin{array}{c}\text { Dissonance resolves to } \\
\text { consonance }\end{array}$ & $\begin{array}{c}\text { Polyphonic layering of } \\
\text { simultaneous melodies, each } \\
\text { in a different key }\end{array}$ & $\begin{array}{c}\text { Highly dissonant with no } \\
\text { resolution to consonance }\end{array}$ \\
\hline
\end{tabular}

Zich was particularly adept at this practice of modernist polyphony, and he uses it to chart his own journey from functional tonality into a post-tonal musical world, as Mína passes from functional social relationships into an irrational psychological space and ultimately to suicide. The process happens in phases, corresponding roughly to the three acts of Vina (see Table 2): Act One is the most tonal, with long passages of luxurious Romantic expressivity. In Act Two, Zich accelerates his process of unravelling, layering his melodic motifs to imply more than one key simultaneously, what is termed polytonal. The short third act has very little tonal syntax whatsoever it is largely post-tonal - thereby enacting an audible rupture that destroys the Mařák family.

\section{Mína, her mother, and the unspoken}

The dramatic pivot of Act Two is Mína's decision to reject Uhliŕ, who insists that this also come at the price of revealing her past to Hošek. Mína finally resolves to tell Hošek everything in a letter. At this point, Hilbert inserted a solo scene for Paní Mařáková when, accompanying herself in an art song at the piano, she finally regains the emotional world of her youth: but this is a nostalgic gesture, turned inward against her daughter. Mína enters and is once again met with stony silence. She writes her letter - 
to the accompaniment of a polytonal fugue, one of the opera's most distinctive features - but before she can give it to Hošek, the volatile Uhlír confronts him and brutally reveals the details of Mína's past. Hošek, confused and overwhelmed, reacts with horror at Mína's deceit; Mína herself then rejects him (and locks him out of the house). From this moment, she refuses to be guided by the moral failings of those around her, despite her deep acknowledgment of her own. With no apparent alternative, she gives herself impetuously over to Uhliŕs's plans for marriage with a mounting hysteria that shocks even him: it is an act just as meaningless and soulless as that of her mother, a generation before.

The most important musical scenes are those that present the deepest chasms between Mína and her mother: the juxtaposition of Paní Mařákovás art song and Mína's polytonal fugue places them into incompatible musical and expressive worlds. Paní Mařáková's art song, 'Kvetla rüže, kvetla z rána,' accompanied by piano in the original, was the sole threepage excerpt published from the opera in Zich's lifetime. ${ }^{14}$ It is melodically beautiful in a traditional, Romantic sense, and largely unrepresentative of the rest of Vina's score; deliberately old-fashioned, it represents the sound world of Paní Maráková's own past, some twenty-five years before the play's 1890s setting (i.e., the early 1870s, in a style resembling that of early Dvořák). Hilbert had originally included the text for Mendelssohn's Volkslied 'Es ist bestimmt in Gottes Rat,' op. 47 no. 4, which was presumably sung at this point in the staged play. Zich considered such a wholesale musical quotation inappropriate for his opera, and therefore constructed his own folk-like poem to which he could then apply his ready-made motif for Paní Mařáková (HUTTER 1922: 31-32). ${ }^{15}$ In allowing her to express herself only in song - which is to say, a song perceived as singing even within the musico-dramatic world of the opera - 'Kvetla rüže' obviates the mother's stunted emotional relationship with her children.

Kvetla růže, kvetla z rána,

Byla láska mezi náma,

Byla láska nejvěrnější,

Dávno, ach, můj nejmilejší.

Když jsme tenkrát na cestičce

Dávali si po hubičce,

Nevědèl jsem, má milá,

Že ta láska skončit má.

Bude vojna, bude, kdo tam na ni piojde,

Ten se se svou milou neshledá,

Už koně sedlají

a muziky hraji,

Až mi srdce v těle usedá.
[The rose bloomed in the morning,

There was love between us,

It was the most faithful love,

But long ago now, ah, my most beloved.

When we gave each other a kiss

On the path that one time,

I did not know, my dear,

That this love could ever end.

War is coming-who will go off to it?

This one will never see his love again.

Already they are mounting horses

And playing the march,

Until my heart sinks into my chest.

14 See fn. 4.

15 See Example 2 for Paní Mařáková's motif. 
Proč pláčeš, naříkáš,

Když mne tu ještě máš́,

Tepro budeš plakat a smutně nařikat,

Až mne neuhlídáś.

Opadal už z růže květ,

Milý můj šel v širý svět,

Ach naposled! Example 3):
Why do you weep and wail

When you still have me here?

You can weep and sadly wail

Once you see me no more.

Already the petals have fallen off the rose,

My beloved has gone into the wide world,

And the road is plowed where he last kissed me,

Ah, for the last time! ${ }^{16}$ (ZICH 2014a: xxiv)

Mína's entrance interrupts the final chord, which Zich choreographs exactly: Paní Mařáková's hand actually falls on a 'wrong note' when she notices her daughter (see

(3) Paní Mařáková's 'wrong note,' Act 2, mm. 478-81.

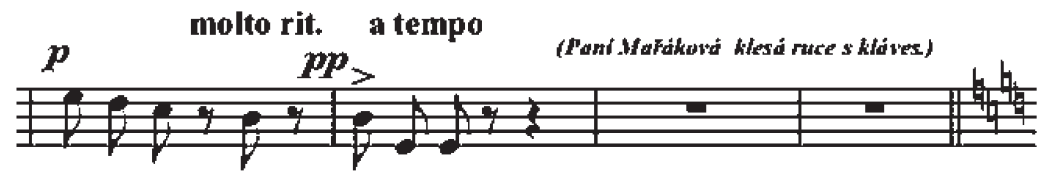

na-po-sled, ach. na-po-sled!

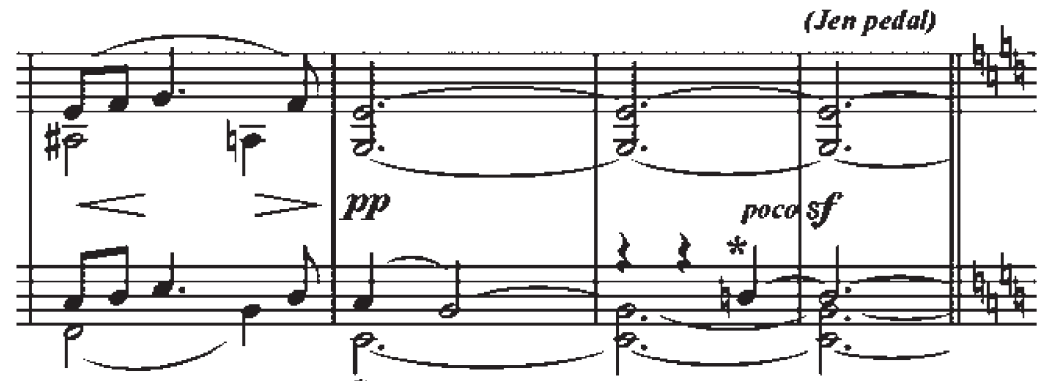

Tou. sempre

${ }^{*}$ Klesajicí levá ruka zavadila o tento kláves.

Mína utters a single word, 'Maminko!' before the older woman leaves wordlessly, and Mína begins her letter. Zich's fugue thus takes shape while Mína silently confronts her thoughts and expresses them on paper: unlike other famous operatic letter scenes, such as those in Mozart's Le nozze di Figaro or Tchaikovsky's Eugene Onegin, we never see or hear what Mína writes. ${ }^{17}$ Rather, it is Zich's music that must serve to express its

16 The corresponding music appears in Act Two, measures 1427-1482 (ZICH 2014b: 365-367).

17 In Act 3 of Mozart's Le nozze di Figaro (1785), the Countess Almaviva and Susanna sing the duet, 'Canzonetta 'Sull' aria', the text of which is the dictation of a letter to Count Almaviva. In Act 1, scene 2 of Tchaikovsky's Eugene Onegin (1879), Tatyana sings the 'Letter Scene' (Пускай погибну я), which contains her faltering revisions of her letter to Onegin. 
contents to us without words. A fugue is one of the iconic forms of Baroque polyphony and was often used by subsequent composers as a historicist reference to sound worlds of the past; but we have just come from Paní Mařáková's musical past, and Mína’s fugue is entirely modern in expression. Fugues are characterized by their main melody, the subject, which enters in successive instrumental parts: unlike the restraint of a Baroque fugue, Zich's wide-ranging subject seems to fly out of control even from the outset (see Example 4). However, Zich does control it, perfectly submitting it to all the manipulations of strict polyphony, appearing in different keys, inversion, retrograde, and overlapping with itself (stretto), until the entire orchestra is involved. It is the central vortex around which the entire musical drama rotates, for it embodies the unspoken, ineffable drama that only Mína can see, but which we can hear. Any trace of the opera's functional tonality has dissipated over its course, each instrumental voice implying a multitude of simultaneous key areas.

(4) The fugue subject, Vina, Act 2, mm. 1499-1508.

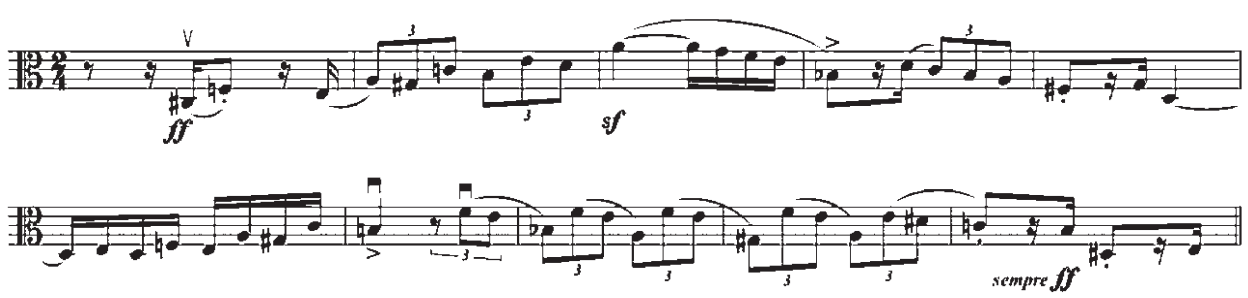

One of the most fascinating aspects of this fugue is that it continues to a formal conclusion despite two successive interruptions, first by Paní Mařáková, who comes in to ask about the laundry, and secondly by Uhlír, whom Mína manages to hold at bay until the letter (and the fugue) are complete. This very continuity is testament to the power that the unspoken idea - represented by the musical idea - has over Mína. Significantly, she never gets to deliver the letter, for the secret is revealed to Hošek and the relationship is irrevocably broken just moments later.

The last act of Vina is the shortest, presenting only a series of dénouements for the different layers of plot. It is also an essentially post-tonal work, one in which fragmentary motivic gestures happen in a harmonic vacuum. On stage, Hošek returns, ready to reconcile with his fiancée's past. Mína, however, cannot take him back after such a moralistic betrayal and her own offer ('as a prostitute') to Uhlír: they part forever. Caught between her perceived moral failure, her mother's rejection, Hošek's pity, and the inhumanity of Uhlír, Mína is driven to suicidal despair. In an instant that evidently emerges from her anguish throughout the entire drama, she breaks a window and leaps to her death. Jiří and Uhlír, discovering the tragedy, are unable to shield the psychological blow to Paní Mařáková, who collapses with guilt over her emotional abandonment of her daughter. The music of the final scene is nothing less than a cacophonous explosion of sound, for no form of traditional melody or harmony could justifiably express the horror of discovering one's own child's suicide. 


\section{Jankélévitch and Zich between sound and silence}

Hilbert's psychological realism meshed so closely with Zich's aesthetic theories for opera that the composer had little to do but trim for length when creating Vina's libretto. The opera's things left unsaid, its silences, and the gradual revelation of Mína's psychological state provided Zich with the perfect framework for his own musical drama. Zich even retained Hilbert's stage directions for silence (ticho), as many as fifteen times in his score, and yet filled all but one of these gaps with orchestral sound (see Example 5). I was struck by this apparent contradiction during the editing process: why retain a functional element from the stage play - effecting a pause for the actors - when the composer can already craft the entire temporal plane of the operatic experience, and in their place give us seemingly the opposite: polyphonic, motivic - yet voiceless - sound? The answer lies partially in Zich's own theory of 'multivocality' within musico-dramatic narrative, but on the point of operatic silence he is mute.

\section{(5) Audible silence in Vina, Act 2, mm. 270-73}

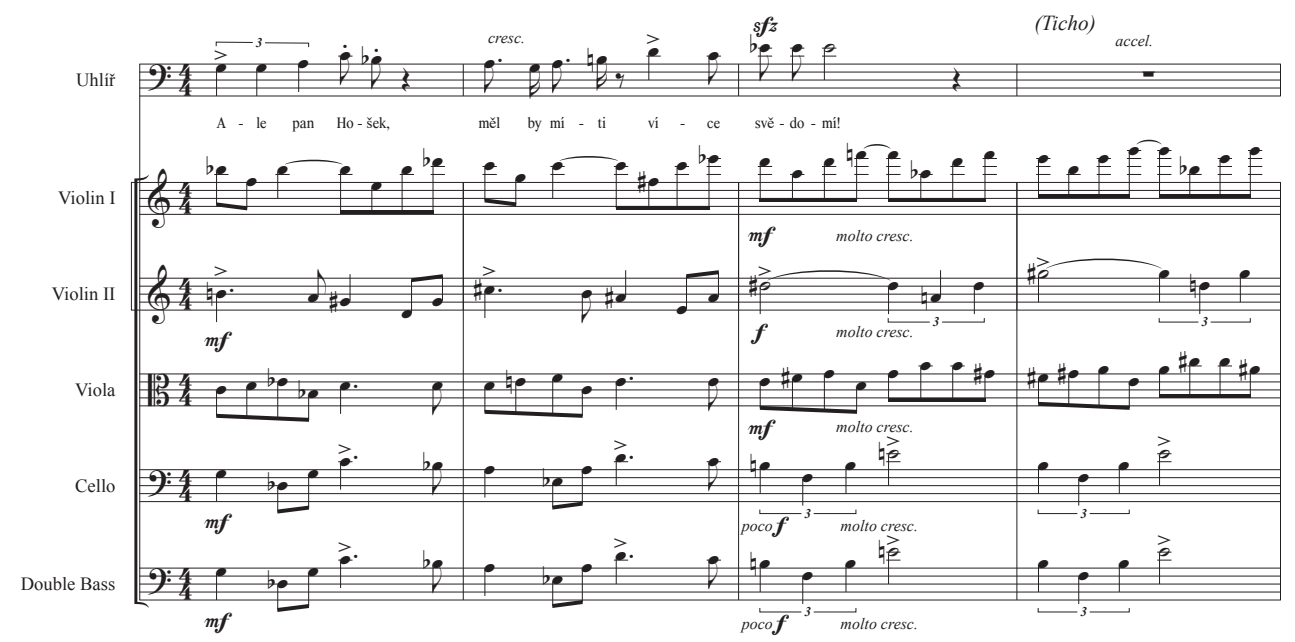

I turn instead to work of the French-born philosopher Vladimir Jankélévitch, who I believe shares an aesthetic kinship with Otakar Zich. A student of Henri Bergson, Jankélévitch happened to be in Prague teaching at the Institut Français in the years 1927-1933, a time when he was already immersed in the aesthetics and ontology of music. His landmark book on the subject, Music and the Ineffable, was completed in 1961. This work represents a deeply moving, thoughtfully written search for the meaning of expression and the nature of the boundaries, as he put it, between the 'I-know-not-what' and 'the almost-nothing. ${ }^{18}$ His final chapter, 'Music and Silence,' offers insights that may unlock the mystery of the fifteen audible silences 
in Zich's score, and many other passages central to the opera's psychological world, including Mína's letter-fugue.

For Jankélévitch, music and silence form a parenthesis for each other, in that all music emerges 'from an ocean of silence' and 'gradually exhausting all possible combinations of sounds, tends inexorably toward silence' (JANKÉLÉVITCH 2003: 130-131). Conversely, silences are a constituent part of music, and even contain their own music (as the American composer John Cage also famously noted). ${ }^{19}$ Jankélévitch posited that only 'Bare time, abstract time, is silent time, but Becoming is filled with events and occurrences, fitted out with concrete contents fashioned from noise. Noises succeed one another and sounds imply continuation, imply it intensely, like the notes a singer sustains and extends with vibrato: time is their natural dimension' (JANKÉLÉVITCH 2003: 131). How Zichian it is to hear Jankélévitch muse, 'Just as architecture is the artifice that fills space with formal volumes, cubes, and towers, just as painting populates a monochromatic surface with colour - that is with the positive polarity, the diversity inherent in multi-coloured splashes - so music and poetry animate time, superficially, by means of rhythm as well as mellifluous noise' (JANKÉLÉVITCH 2003: 132).

More than superficially, these sound worlds also echo our own ontology: 'Life floats like a raft on this great volume of silence, a silence that makes all human noise a bit precarious, and makes the enchanted island that is art so precious' (JANKÉLÉVITCH 2003: 132). 'Music stands out from silence and has need of silence in the same way that life has need of death, and thought [...] has need of nonbeing' (JANKÉLÉVITCH 2003: 132). '...[C]onversely, death is a form of stagnation, which, arresting the process of Becoming as it does all movement, forces loquacious events to fall into silence' (JANKÉLÉVITCH 2003: 131). Pure silence, then, is beyond the cusp of every sound world, in nonbeing, whereas it would seem that the passing, audible silences throughout Zich's Vina occupy a rather different plane.

Jankélévitch has a mode for these sonorous pauses which he whimsically calls 'le presque-rien' or 'the almost-nothing.' Indeed, many of Zich's fifteen instances of 'ticho' have only very quiet or low, sustained instrumental sounds, of the type that brought Jankélévitch tremendous delight: 'The pianissimo, though still audible, is the almost imperceptible form of the supersensory: it is hardly perceptible. On the border of the material and the immaterial, of the physical and the transphysical, the almost-nothing designates minimal existence, beyond which would be nonexistence, nothing pure and simple' (JANKÉLÉVITCH 2003: 142). ${ }^{20}$ 'What do they tell us, these moments where implications are left hanging? They are saying, Finish this yourselves because I have said too much' (JANKÉLÉVITCH 2003: 141).

The specific location of Zich's silences also resonates with Jankélévitch on the microcosmic level; Jankélévitch notes, 'when pointless conversations cease, music (like supplication) will populate the empty space. With this, music buoys up the heavy weight of logos, loosens the devastating hegemony of the word, and prevents the human genus

19 See, for example (CAGE 2013).

20 Emphasis in the original. 
from becoming overidentified with the spoken alone' (JANKÉLÉVITCH 2003: 140). Over the course of the opera, Hošek and Mína have several conversations about the nature of guilt, confessions, and moral obligations, discussions which recur with increasing tension. Hošek grows wary, exasperated, and, finally, frantic with Mína's questions and their ensuing silences. Zich most often responds with Jankélévitch's 'almostnothing,' as in the following cryptic exchange:

MíNA: (hesitantly) Stáňa, is a person obliged . . . Do you think when someone gets over internal repentance by his own guilt, that he is still obliged through confession to someone else? [...] HošEk: It's up to the guilty party to decide that. (silence)

MíNA: (with sad calm) Stáňa, you will find out a lot today. ${ }^{21}$

Zich fills this silence completely, albeit triple-piano, with low brass, bassoons, and timpani; the last of these serves as the sole accompaniment to Mína's 'sad, calm' response. ${ }^{22}$ At other times, Zich uses audible silences to increase dramatic tension, as in the three successive gaps that follow Hošek's accusation, 'You always hint so much and never finish saying anything!'”23 After each of his repeated - but unanswered - questions, Zich's orchestra presents an unsettling cacophony at an increasing volume: low string statements of Hošek's motif are punctuated by dissonant chords in the horns.

Although not designated 'ticho' per se, the polytonal letter-fugue is clearly an extended silence, where music 'loosens the devastating hegemony of the word'; it is also the moment when Mína finally breaks her silence about her guilt. Notably, this follows the opera's only scene of on-stage musical performance: her mother's art song, which was itself another form of breaking silence. Mína's letter, however, is substantially louder than any of the vocal music in the opera, and in sound it expresses secrets she never gets to share: they remain ineffable, even to us. This is also when Zich's score passes from functional tonality into the post-tonal world.

The only one of Zich's silences with no notated music occurs near the end of Act Two, once Uhlír has revealed Mína’s secrets to Hošek and he has rejected her. Twice she shrieks 'Go!' ('Jdi!') at the top of her range, followed by two and a half measures of rest. ${ }^{24}$ It is her breaking point: the moment beyond which lies her surrender to Uhlír, her confession to her family, and ultimately, her death. All of these are ruptures that the silence anticipates. Jankélévitch explains this effect too: 'in general it is rather

21 'Mína: (váhavě) Stáňo, je člověk povinen... Myslǐs, když si někdo odbyl vnitřni pokání za svou vinu, že je ještě někomu povinen zpovědi? [...]

Hošek: To rozhodnout je věci vinika. (ticho)

Mína: (se smutným klidem) Stáňo, ty se dnes mnoho dovís.' (ZICH 2014a: xix)

22

Act One, measures 1227-1230 (ZICH 2014a: 156).

23 'Ty toho vždy tolik napovís a nic nedořekneš!' The three ticho stage directions appear after Hošek's lines, 'You are not as frank, however, as you think! (silence) [...] Why do you not answer? (silence) Minka! (silence) (Tak upř́mnou přec nejsi, jak si myslís (ticho) [...] Proč neodpovidášs? (ticho) Minko! (ticho)).' The musical passage in question is in Act One, measures 801-827 (ZICH 2014a: xvii and 102-104). 
a prophetic silence $[\ldots]$ and to the degree that initial silence is a promise, or a threat, terminal silence designates instead the nothingness to which life returns: music born of silence returns to silence' (JANKÉLÉVITCH 2003: 133). ${ }^{25}$ But if the intimation of her death is noiseless, her actual death is anything but. When Mína commits suicide by jumping through a glass window, we hear a shattering cacophony scattered throughout the entire orchestra part: blaring trumpets, hammering blows in the horns and strings, trilling flutes and bassoons - even the harps are discordant. ${ }^{26}$ It is the roar of death, of the life left behind, and in defining this inversion, Jankélévitch could be describing the grief of Paní Mařáková: 'the person assailed by cacophony, covering [her] ears, wants to protect [her] slip of a silent garden, shelter [her] little islet of silence, because henceforth it is silence that insulates, and not noise' (JANKÉLÉVITCH 2003: 135).

For the Prague critics of 1922, it was noise: they decried Zich's efforts as 'ruthless polyphony' and even 'finis musica' - the end of music itself (ŠOUREK 1922; ŠILHAN 1922). ${ }^{27}$ Their reactions, prompted largely by partisan spite, also reveal an all-toocommon resistance to modernist music that pervaded Zich's generation. It is rather a stunning thought that any music could end all music. Nevertheless, after Zich's death in 1934, a silence descended over Vina lasting most of a century. ${ }^{28}$ That silence ends tonight. ${ }^{29}$

25 Emphasis in the original.

26 Act Three, measures 986-1016 (ZICH 2014c: 572-74).

27 Šourek's judgment is: 'Neřikám, že by partitura „Viny“ dovedla mnoho změniti na dřivějším úsudku, že Zich neni individualitou se silným hudebním fondem a vynálezavosti. Ani nynějši krajně modernistický ráz jeho projevu, jeho odvaha ke stavbě složitého, harmonicky bezohledného mnohohlasu nesmi nás v tom mýliti... [I do not say that the score of Vina could change much in earlier judgment that Zich is not an individual with a strong music basis and inventiveness. Neither the present-day ultra-modernist character of his expression [or] his courage to build complicated, harmonically ruthless polyphony can contradict us...].' For further reading about the critical reception of Vina, see (LOCKE 2006: 169-178).

28 The opera was performed nineteen times in Zich's lifetime across two productions, dated 1922 and 1929. No complete performance is known after 30 May 1929. All performances were conducted by Ostrčil. The fourth horn part also lists a performance of excerpts from the opera conducted by Iša Krejčí on 19 September 1934, roughly two months after the composer's death.

29 The 2018 conference featured a gala performance of excerpts of Vina, performed for the first time since 1929, in a two-piano arrangement by Brian Locke. The excerpts consisted of the entire Act One, the central scene of Act Two (Píseñ pani Maŕákové and the polytonal fugue), as well as the final moments of Act Three. 


\section{Bibliography}

ABBATE, Carolyn. 1991. Unsung Voices: Opera and Musical Narrative in the Nineteenth Century. Princeton: Princeton University Press, 1991.

BURJANEK, Josef. 1966. Otakar Zich: studie k vývoji českého muzikologického myšleni v pruni třetinĕ našeho stoleti [Otakar Zich: Studies in the Development of Czech Musicological Thought in the First Third of Our Century]. Prague: Státní pedagogické nakladatelství, 1966.

CAGE, John. 2013. Silence: Lectures and Writings. Middletown, Conn.: Wesleyan University Press, 2013.

HUTTER, Josef. 1922. Otakar Zich a jeho hudebni drama 'Vina': poznámky a rozbor díla [Otakar Zich and His Musical Drama, Vina: Notes and Analysis of the Work]. Prague: Melantrich, 1922.

JANKÉLÉVITCH, Vladimir. 1957. Le je-ne-sais-quoi et le presque-rien. Paris: Presses universitaires de France, 1957.

JANKÉLÉVITCH, Vladimir. 2003. Music and the Ineffable. Transl. by Carolyn Abbate. Princeton: Princeton University Press, 2003.

JUSOVÁ, Iveta. 2004. Re-inflecting Femininity on the Czech Fin-de-siècle Stage: An Analysis of Hana Kvapilová's Acting Style. Theatre History Studies 24 (June 2004): 35-56.

LOCKE, Brian S. 2006. Opera and Ideology in Prague: Polemics and Practice at the National Theatre, 1900-1938. Rochester, N. Y.: University of Rochester Press, 2006.

LOCKE, Brian S. 2008. The 'Wozzeck Affair': Modernism and the Crisis of Audience in Prague. Journal of Musicological Research 27 (2008): 1: 63-93.

[N.a.] 1922. Ot. Zich: Vina (Revue kritik) [Otakar Zich: Vina (Overview of Criticism)]. Tempo Listy Hudebni matice 1 (April 1922): 7: 104-107.

PALA, František. 1964. Opera Národního divadla v obdobi Otakara Ostrčila [Opera at the National Theatre in the Era of Otakar Ostrčil], vol. 2. Prague: Divadelní ústav, 1964.

SCHIANO, Michael J. 2001. Grundgestalt [online]. Grove Music Online [accessed on 21. 5. 2019]. Available online at https://doi-org.wiulibraries.idm.oclc.org/10.1093/gmo/9781561592630. article.11868.

SCHOENBERG, Arnold. 1950. Linear Counterpoint. In Leonard Stein (ed.). Style and Idea: Selected Writings of Arnold Schoenberg. Transl. by Leo Black. New York: Philosophical Library, 1950: 289-295.

SCHOENBERG, Arnold. 1975. Opinion or Insight? In Leonard Stein (ed.). Style and Idea: Selected Writings of Arnold Schoenberg. $2^{\text {nd }}$ ed., Transl. by Dika Newlin. New York: St. Martin's Press, 1975: 258-264.

ŠILHAN, Antonín. 1922. Finis musicæ [The End of Music]. Národni listy (15. 3. 1922).

ŠOUREK, Otakar. 1922. Otakar Zich: Vina. Venkov (16. 3. 1922).

ZICH, Otakar. 1914. Moderní opera [Modern Opera]. Osvěta 44 (1914): 481-493; 569-579.

ZICH, Otakar. 1922. Píseñ pani Mařákové [Mrs. Mařáková's Song]. Prague: Em. Starý, 1922.

ZICH, Otakar. 1927a. Dramatické možnosti opery [The Dramatic Possibilities of Opera]. In Josef Kodíček and Miroslav Rutte. Nové české divadlo 1918-1926. Prague: Aventinum, 1927: 84-91.

ZICH, Otakar. 1927b. Jak se komponuje opera [How One Composes Opera]. In Nové české divadlo 1927. Prague: Aventinum, 1927: 86-88.

ZICH, Otakar. 1933. Autoři o sobě. U mistra Otakara Zicha [Authors about Themselves: With Maestro Otakar Zich]. Česká hudba 36 (15. 1. 1933): 9: 132-135.

ZICH, Otakar. 1977 [1931]. Estetika dramatického umění [The Aesthetics of Dramatic Art]. Reprint ed. Oleg Sus. Würzburg: Jal-Reprint, 1977. 
ZICH, Otakar. 2014a. Vina [Guilt], vol. 1. Ed. by Brian S. Locke. Middleton, Wisc.: A-R Editions, Inc., 2014.

ZICH, Otakar. 2014b. Vina [Guilt], vol. 2. Ed. by Brian S. Locke. Middleton, Wisc.: A-R Editions, Inc., 2014.

ZICH, Otakar. 2014c. Vina [Guilt], vol. 3. Ed. by Brian S. Locke. Middleton, Wisc.: A-R Editions, Inc., 2014.

ZICH, Otakar. n.d. The Aesthetics of Dramatic Art. Transl. by Ivo Osolsobě [unpublished typescript].

ZICH, Otakar. n.d. Vina [Guilt]. Autograph orchestral score, piano-vocal scores, orchestral parts, and libretto. Prague: Hudební Archiv, Národní divadlo v Praze, MS. H 177.

\section{Professor Brian Locke}

School of Music, Western Illinois University,

122 Browne Hall, 1 University Circle. Macomb, IL 61455, USA

B-Locke@wiu.edu

Brian S. Locke earned a Ph.D. in Musicology from Stony Brook University (2002) and is currently a professor of Musicology at Western Illinois University. His specialization covers many generations of Czech and Bohemian music, including such varied figures as Gluck, Novák, Zich, Schulhoff, Ježek, Traxler, and Feld. In 2014 he edited a scholarly edition of Zich's 1922 opera, Vina (A-R Editions, Inc.). 